\title{
Identifying Effects of Information Asymmetry on Firm Performance
}

\author{
Anne Khatali \\ Finance and Accounting Department, ESPAG, Nairobi, Kenya \\ Email address: \\ khatali.k.anne@gmail.com
}

To cite this article:

Anne Khatali. Identifying Effects of Information Asymmetry on Firm Performance. International Journal of Economics, Finance and Management Sciences. Vol. 8, No. 2, 2020, pp. 75-83. doi: 10.11648/j.ijefm.20200802.12

Received: July 12, 2018; Accepted: September 26, 2018; Published: May 28, 2020

\begin{abstract}
There is a lot of information asymmetry in the market today. Sellers in most cases have superior information over buyers and as a result beat market logistics to make as much profits as possible at the expense of buyers. Information asymmetry among market participants translate into high transaction costs and lower liquidity in the markets. Having superior information over other market participants lead to unfair competition in the market, especially in the stock markets due to insider trading. In a firm set up, I. A occurs when a manager in charge of planning and implementation of important decisions for achievement of firm's objectives has superior information over owners, who are shareholders of the company. Managers are at discretion to make decisions without necessarily involving inputs from shareholders of the firm because they are charged with full responsibility of running affairs of the firm. This paper analyzes and tests effects of information asymmetry on firm performance at a micro-level. We analyse this paper using panel data, precisely financial statements from companies listed on the New York Stock market for a period of ten years. Using the same data we regress the model to estimate the effect level on firm performance. Fixed effects test is estimated and inference is based on significant level or p-value thus likely that less than 0.05 is rejected at a $95 \%$ confidence level, less than 0.01 is rejected at $99 \%$ confidence level and less than 0.1 is rejected at $90 \%$ confidence level. The results however show that information asymmetry is significant at $10 \%$ indicating it has effect on firm performance. However on regressing return on assets on other variables, results indicate that information asymmetry is significant at both $5 \%$ and $10 \%$ significant level.
\end{abstract}

Keywords: Information Asymmetry (IA), Principle-Agency Costs (PA), Socially Responsible Investment (SRI), Earnings Management, Turnover, Spread (Bid-ask Spread), Generally Accepted Accounting Principles (GAAP)

\section{Introduction}

Most cases indicate that managers in charge of firms have superior information about a firm or and an industry they are in charge of compared to owners and potential investors. As much as they have knowledge on profitable and risky investments, Managers are also in charge of preparing financial statements which IFRS gives flexibility to choose accounting methods preferred by the firm. Interested parties like shareholders and potential investors have no choice but rely on information displayed in these financial statements as true, fair and free from interference.

Information asymmetry therefore occurs when one party in a transaction is perceived to have more or superior information compared to the other party, as a result a party with superior information takes advantage to beat the market and earn abnormal profits or achieve personal ambitions.

However, an information gap between two parties in a transaction leads to information asymmetry which has important implications on firm performance. Effect of information asymmetry could be positive or negative depending on intentions of managers who are in charge of running company affairs in order to maximize shareholder wealth.

Managers have a tendency of providing private information through accounting choices, practices that would influence decisions and beliefs of rational investors. Example, managers are free to announce dividends after closure of books of accounts at the end of the accounting period. As a result, managers with intentions other than maximizing shareholders wealth make dividends announcements even if the company's performance is not 
good because announcing dividends could reflect a positive performance about the firm even if the firm's performance is below standard. However if potential investors use information provided in financial statements to make important investment decisions that later on prove negative, it could damage the image of the firm eventually leading to poor performance in the market.

It's also not easy to measure the anticipated intention of managers at that particular period when making important decisions on behalf of the firm. Even though it's not always true that decisions made by managers are for personal interest, on the contrary, important decisions with the aim of maximizing shareholder wealth could also be made.

\subsection{Theoretical Background}

Information asymmetry was introduced first by Akerlof in his paper [1] the market for "Lemons"; quality uncertainty and market mechanism. Akerlof developed asymmetry Information with a case of auto-mobile market. He argued that buyers use market statistics to measure the value of products. The buyer on average sees the whole market while the seller has more intimate knowledge of specific products in their possession. Akerlof argued that information asymmetry gives the seller an incentive to sell goods of less than average market quality to unsuspecting buyers.

In the market, daily transacting of activities has the seller in possession of superior knowledge about the products quality and real price but since the buyer has general information about the product from other buyers who previously used the product, then chances of paying a high price for "lemons" in the market are high because the real product selling in the market may not find buyers due to higher price tag compared to "lemons" prices as reflected in the paper of "lemons" on quality uncertainty and market mechanisms.

Information asymmetry can also be argued on the basis of hiring personnel in the firm. Employers (shareholders) have no idea whether managers being hired have ability to take care of firm affairs with utmost competence and integrity. Michael Spence, [2], divides the market into two parties; few and numerous players in the market, a case of hiring employees as an investment decision under uncertainty. Furthermore an employer may not be aware of productive capabilities of an individual before hiring except where a company carries out its own training program for new employees.

Literature identifies IA as a defining characteristic of credit markets and insurance companies. Client borrowing money from a bank has their credentials screened before lending is done by the bank. Furthermore a bank may still be uncertain about the ability of the borrower to repay the principal plus interest due to future uncertainties. It's also impossible for the borrower to know bank criteria used in order to allocate interest on loan awarded.

Another case study is that of an insurance company and insured person. A lot of information asymmetry exists due to adverse selection and moral hazard. Insurance companies give clients a form to fill in order to get as much information from them as possible. This information helps determine amount of premiums allotted to clients should they choose to be insured. Once forms are filled, it's not easy to tell whether information provided is true and trustworthy. For example, it's not easy to tell if a client in an insurance contract will observe all the rules and whether the client's actions will mitigate risk.

\subsection{Mitigation of Principal Agency Costs}

Studies have been carried out to find ways that can mitigate information asymmetry between two parties in a transaction. Research indicates that firms participating in corporate social responsibility have huge analysts following which helps put in check activities of managers for fear of being jeopardized by shareholders, government and investors at large who have invested financially in the firm. Security analysts also cover more on corporate responsible firms to an extent that it mitigates conflict of interest between managers and shareholders reducing information asymmetry.

In his paper, EL Ghoul et al [3] claims that information asymmetry is likely to be more severe for firms with low corporate social responsibility because of less disclosure about firms activities as compared to socially responsible firms whose activities are well followed by analysts, potential investors and public at large. Dan S Dhaliwal [4] shows evidence that initiation of voluntary CSR disclosure provides information to the market which reduces firm's cost of capital and analyst divergence. Dhaliwal also finds evidence that CSR reports lead to lower analyst forecast errors especially for countries with more opaque information environment.

Research also suggests that new accounting regulations improves transparency and reduces information asymmetry among capital participants as was the case of Christian Leuz and Peter Wysocki on "The economics disclosure and financial reporting [5]". Furthermore a switch from conventional accounting to new accounting methods indicates that more information is being conveyed through financial statements data and as a result more investors and analyst scrutiny has led to a decrease in information asymmetry.

\subsection{Justification}

Information asymmetries exist on a daily basis between two parties in a business transaction; one player has superior information over the other. Moreover a seller has superior information about product quality whilst a buyer has an average idea of the whole market [1].

From the 1970's modern economic thought has been revolutionized taking an example of Modigliani-Miller theorem which concludes that firm value is independent of its financial structure. There is need for provision of incentives to align the interests of managers and workers with those of shareholders.

Introduction of International Financial Reporting 
Standards has helped most companies move from conventional accounting to new accounting era where information to be given out is well arranged through standardized accounting procedures and policies which has led to a common and standardized method of preparing financial statements reducing information asymmetry in firms.

Financial standards require all limited companies to publish audited financial statements in their prospectus at the end of every financial year because potential investors rely on them for making investment decisions. Shareholders also view audited financial statements to know performance of the firm [6].

Shareholders put in place policies that act as quality control measures to mitigate information asymmetry between management and employees through stock options and merit based salaries in order to align objectives of managers to those of shareholders. This study provides baseline information on effects of information asymmetries on firm performance and how well these effects can be mitigated.

\subsection{Objectives}

\subsubsection{General Objective}

This study examines effects of IA on firm performance, to know and understand how this affects performance of the company when managers engage in activities that put at risk shareholders wealth.

\subsubsection{Specific Objectives}

Demonstrate effect of information asymmetries on performance of companies listed on the stock market from the Wall Street Journal.

(1) Using financial statements; balance sheet and income statement we determine how information asymmetry affects performance of firms from the shareholders perspective by analysing significance of variables on firm performance.

(2) Using empirical evidence and output obtained by regression, a proposal of recommendations is made regarding effect of information asymmetry on firm performance.

\subsection{Hypotheses Development}

As discussed above, information asymmetry increases principal agency costs between two contracting parties because one of them has superior information over the other. The party with superior information uses it to make abnormal profits or for their own selfish ambitions.

As a result many firms come up with different strategies to mitigate the agency problems leading to greater demand for firms to prepare financial statements in accordance to IFRS and generally acceptable accounting principles, hiring a licensed auditor to carry out auditing and investigations on activities of the firm, authenticate financial books of the firm before drawing conclusions as to whether firm's performance reflect a true and fair view.
Hence, my hypothesis stated in alternative form is as follows:

(1) H0: $P=0$ Information asymmetries has no effect on firm behavior

Under this assumption, a perfect and complete market is presumed where there is no information asymmetry. All the parties in the contract have access to relevant information that will help in making decisions.

(2) $\mathrm{H} 1: \mathrm{P} \neq 0$ Information asymmetries has effect on firm behavior

Firm performance could be attributed to sales turnover, performance of the shares of the firm on the stock market, profitability of the firm, and the growth rate. The alternative hypothesis tends to seek the magnitude of effect caused by information asymmetry and how it affects major decisions made by firm's management.

Therefore my alternative hypothesis seeks to identify these effects that could alter performance of firms.

\section{Literature Review}

It is empirically clear that people possess different information which affects their behaviour in particular ways. In any business transaction a seller with superior information is likely to adjust prices of goods depending on knowledge of price and quality of similar items in the market. However, a buyer does not have same depth of information about quality of the items which makes it easy for price manipulation by a seller in order to make abnormal profits.

Information Asymmetry occurs when principal-agency problems arise due to conflict of interest between two major players, "shareholders and managers in a firm. It's quite often the case whenever two parties engage in a business transaction as was the case of George Akerlof on "markets for lemons [1]"

Secondly, it has been suggested that managers engage in discretionary accrual accounting which leads to information asymmetry. Managers are at discretion to anticipate an expense which is yet to be recognized in the books of accounts. This however provides managers with opportunities to manipulate earnings due to flexibility provided in IFRS [7].

IFRS gives managers flexibility to determine certain accruals, so managers use this privilege to manipulate earnings for their own selfish ambitions. According to Paul M Healy on "The effect of bonus schemes of accounting decisions" [8] managers engage in unethical behaviour of using accruals to maximize their bonuses. B. Brian Lee and William Vetter on "Critical evaluation of Accruals models in earnings management, [9] suggest that since discretionary accruals are arbitrary in nature, managers make judgements in connection to their bonuses not supported or linked to assets or liabilities of the firm.

Managers are also in charge of announcing reported earnings and since they have private information about firm value, their compensation is tied up to firm value which they may use to announce earnings far from truth by engaging in 
manipulation of accounting earnings as suggested by Kenneth Dury and Alexandros Tsitinidis on "managerial incentives and earnings management [10]."

International Financial reporting standards under GAAP suggests that managers can freely influence certain balance sheet items like writing off bad debts, choosing a method to depreciate the company fixed assets and expensing inventory (LIFO, FIFO or weighted average method). Since managers are in charge of planning and executing major decisions of the company, then the IFRS allows them to time real transactions that would alter the output of the firm whether in their favour or not.

Due to this flexibility of accounting policies and concepts managers can engage in activities that would reduce the firm value because all these major decisions are made without knowledge of shareholders.

\subsection{Mitigation of Information Asymmetry}

Information asymmetry can however be mitigated by firms reducing principle agency costs. Different firms come up with different strategies that could help mitigate information asymmetry as much as possible.

For example, banks are known for carrying out independent tests to screen credit worthiness of a client in order to get more information that is used to assess interest rates on loans awarded to potential clients which help mitigate information asymmetry [11]. Knowing the occupation, cash-flow, age, and basic history of a client in terms of previous loan payments helps banks access the ability of clients to repay loans plus interests.

Firms with high analyst coverage have a reduced level of information asymmetry since analysts gather as much information as possible about them which is displayed to the public through newspapers, economic websites, social media discussions and stock market journals. This helps potential investors access as much information as possible about the firm before making investment decisions. Shareholders also use this information to gauge the performance of their firm by comparing with similar firms in the industry [12].

It's prudent for most firms to voluntarily disclose relevant information which will help reduce information asymmetry among informed and uninformed investors. Douglas Diamond and Robert E Verrecchia, on "Disclosure, liquidity and the cost of capital", [13] suggested that voluntary disclosure by management helps boost the confidence of investors in the stock prices of the company because they deem prices to be fair which eventually leads to increased liquidity in the firm's stock.

Furthermore firms that voluntarily make available relevant information to potential investors and public at large, have high stock prices compared to firms that do not because investors are confident in a firm they trust to reflect a true and fair view [14]

It's also important for firms to disclose their financial statements and notes, dully signed and certified by an independent auditor. Such information helps build trust between potential investors, managers and owners of the company. When more information is disclosed, imbalance of orders between informed and uninformed investors reduces information asymmetry [15]

The main purpose of having an external auditor to carry out an investigation on final accounts of the firm is to enhance credibility of financial figures to potential investors who are more likely to trust audited financial figures than non-audited figures. High quality audit reduces information asymmetry between informed managers and other shareholders in the firm by building trust among interested parties in the firm. Auditors reduce information asymmetry by offering independent verification of financial statements and reporting breaches in the books of accounts.

On the stock market firms that voluntarily disclose information improve liquidity. This occurs because information asymmetry helps reduce information gap between buyers and sellers on the market [16].

Shareholders help reduce agency costs that exist between them and managers by practically allowing managers to own a certain percentage of shares, psychologically allowing management to own the company and as a result act ethically towards the interests of all by maximizing firm value and shareholder wealth which they are part of.

Since it's well known that managers' compensation is linked to firm value, managers with superior information over shareholders manipulate accounting figures in order to increase perceived value of a firm. In most cases managers are known to engage in earnings management which increases information asymmetry. However shareholders put in place dividend policy that ensure a certain percentage of profits are issued out as dividends to shareholders at the end of the year. This act helps reduce amount available for misuse or disinvestment by managers through manipulation of profits.

\subsection{Empirical Evidence}

Managers' compensation is linked to firm value, the more profitable a firm is, the higher incentives allocated in terms of salaries and bonuses. Managers who have superior information over shareholders may manipulate accounting figures in order to increase perceived value by painting a true picture of firm's profits. In most cases engaging in earnings management due to more information asymmetry which occurs when earnings are pushed from one period to the other for their selfish interests.

To mitigate any possibility of principal agency costs shareholders put in place dividend policy that would ensure a certain percentage of profits is issued out as dividends to shareholders at the end of the year whilst a certain percentage is kept as retained earnings which managers may decide to use for investment or keep it as a reserve for future use. This act helps reduce amount of money available for misuse or disinvestment by managers due to the costs faced when profits are manipulated. As a result empirical evidence suggests that dividends limit the practice of earnings management by penalising managers who engage in manipulation of financial figures. 
GAAP allows management to exercise judgement when preparing financial statements. This includes determining a period in which marketable securities should be held and how inventories should be expensed. However, research indicates that managers take advantage of GAAP flexibility to increase incentives through reported earnings. Paul M Healy on "the effect of bonus schemes of accounting decisions"[8] Carried out an empirical research using data of firms in the period 1930-1980; the results suggested that managers chose current period's bonus and expected value of the preceding year's bonus. Using total accruals as a proxy for discretionary accruals, the hypothesis indicated that when earnings are expected to fall between upper and lower bound, managers make income increasing choices and when earnings are above the upper bound, managers shift income to future periods to maximize multi-period compensation.

Evidence from secondary loan market on the role of information asymmetry \& financial reporting quality in debt contracting suggested that high quality financial reporting reduces information costs associated with debt agreements increasing efficiency of secondary loans. The analysis was carried on data from the years 1963-2003 using a time series regression estimation restricted to 10 observations for each borrower with a data of 222 borrowing firms.

It was suggested that because of availability of quality information through financial statements then public firms were accessing loans at a lower cost compared to private firms whose costs were high due to high information asymmetry environment.

However on loans, bid ask spread regression analysis for a full sample of publicly reporting and private firms indicated a significant result that bid-ask spread in secondary loan market is positively related to firms and loan specific characteristics associated with high information asymmetry environment, [17]. Evidence from secondary loan market suggests that bid-ask spread is positively related to the firm and characteristics associated with high information asymmetry.

\section{Data and Methodology}

\subsection{Research Design}

This paper examines 22 companies listed on the New York stock market. Companies range from Automotive, financial, technological, energy and transportation sectors. The main collective data for the study includes annual sales of the firms, return on assets, leverage ratio and capitalization (debt + equity) of each firm at the end of year.

Data is downloaded from wall street journal website (www.wsj.com), 22 companies listed on the New York stock market for a period of ten years. Main data was daily prices of stock in the market from 3/ Jan/2006 to 13/April /2016.

A total of 220 observations are sampled from the daily sales price of the companies ranging from 1/3/2006 to 4/13/2016. Data comprising 220 observations is used to calculate the proxy of Information asymmetry which is the bid-ask spread that measures the liquidity of the stock market.

Since spread is directly associated with trading volumes of shares, price volatility, share prices, firm size and listing on the stock markets; these variables also have a direct interaction with information asymmetry as explained below;

(1) Trading volumes - as explained by Gary C. Sanger and Geoffrey Booth on "Trade size and components of bidask spread [18] suggest that informed investors prefer to transact in large volumes of stock in order to take advantage from their private information and as a result this brings disequilibrium in the market causing less informed investors to pay more costs that have to be recouped by the spread. Empirical analysis indicate a negative relationship between spread and trading volumes

(2) Firm size - considered also a proxy for information asymmetry and agency costs. Small firms tend to incur high levels of information asymmetry compared to large firms. Results indicated a positive relationship between size and spread as was suggested by Joon Chao on, "Trading, volume, information asymmetry and timing information [19].

(3) Price volatility - Suggests that any change in prices due to change in what investors expected leads to an increase in the variance of returns. Results indicated a negative relationship between liquidity and volatility of prices as suggested by Joon Chao [19].

(4) Listing on the stock market- Listing makes it possible for analysts to follow the firm and at the same time any firm listed on the stock market is required to disclose their true financial statements which reduce the level of information asymmetry between shareholders and management of the firm.

Why did I choose to use the spread as my proxy for information asymmetry?

The fact that an investor is willing (bidding) to pay an amount that is less than what the seller is (asking) to sell for the security indicates that the seller and the potential buyer have different information endowments that lead to information asymmetry.

\subsection{Spread}

The independent variable information asymmetry is measured by the value of spread.

The model of Shane A and Corwin P on "Simple way to estimate Bid-Ask spread [20] is used to measure spread.

Spread - denotes the bid - ask spread

(1) The model estimates bid ask spread by comparing high - Low price ratios over a one and two day interval

(2) Daily high prices are denoted buy orders while daily low prices are sell orders

(3) High to low prices for a day reflects both the fundamental volatility of the stock and its bid-ask spread

(4) Sum of price ranges over a one "two day period" 
reflects two days volatility and twice the spread while the price range over a one two day period reflects two days volatility and one spread.

ASSUMPTIONS:

(1) Stock values do not change while the market is closed

(2) Price is observed continuously

(3) Stock trades continuously

Stock variance is the natural log of the ratio of High to low prices

(1) Assumes that spread of $\mathrm{S} \%$ is constant over a two day period

(2) Because of spread observed prices of buy orders are higher than actual values by $(\mathrm{S} / 2 \%)$ and observed prices of sell orders are lower than actual value by $(\mathrm{S} / 2 \%)$

(3) High price of the day is a buy order grossed up by $1 / 2$ of the spread while the low price of the sell order is discounted by $1 / 2$ of the spread

We compute standard deviation (sigma) to capture the variance between two day estimation periods of stock prices.

$$
\sigma^{2} \mathrm{HL}=1 / \mathrm{T}^{\mathrm{K}} \Sigma^{\mathrm{T}} / \mathrm{t}=1\left[\ln \left(\mathrm{H}^{\mathrm{A}} \mathrm{t} / \mathrm{L}^{\mathrm{A}} \mathrm{t}\right)\right]^{2}
$$

We find the value of gamma which is the square of the difference between the log of maximum high price and maximum lowest price of the stock prices between two consecutive days.

$$
\alpha=[\ln (2+\mathrm{s} / 2-\mathrm{s})]
$$

$\mathrm{Y}$ is our gamma in this case

Spread is computed using exponential for constant purposes.

$$
\text { Spread }=\left[\left(2 \mathrm{e}^{\mathrm{Y}}-1\right) /\left(1+\mathrm{e}^{\mathrm{Y}}\right)\right]
$$

\subsection{Secondary Data}

Secondary data stems from financial statements of firms listed on the stock market, comprising of annual leverage ratios, annual sales, capitalization and return on assets used as control variables in the model. Dou Atoure and Tunde Kovacs model [21] is used as indicated below in table 1 . The paper attempts to ensure a sturdy (robust) kind of model set by choosing and selecting control variables that have great influence on firm performance.

\begin{tabular}{|c|c|c|}
\hline Definition of control variables & Measurement & $\begin{array}{l}\text { Auteurs } \\
\text { (Author) }\end{array}$ \\
\hline $\begin{array}{l}\text { Financial leverage(FL) i.e. debt } \\
\text { ratio }\end{array}$ & $\begin{array}{l}\text { Computed on the basis of total debts in proportion to total assets i.e. total liabilities at the end of period } \\
\text { divided by total assets at the end of period }\end{array}$ & [22] \\
\hline Firm size & Computed on the basis of yearly sales at the end of the period & [23] \\
\hline Return on Assets & $\begin{array}{l}\text { Profit in proportion to total assets. Used because firms with high profitability pay more cash profits } \\
\text { Measured by dividing net income with total assets }\end{array}$ & [24] \\
\hline
\end{tabular}

Control variables

Table 1. Definition and variable measurements.

\subsection{Methodology}

This model comprises of one independent variable (Information Asymmetry) and control variables; leverage ratio, firm size and return on assets.

We analyse the effect of IA on firm behaviour using the model below.

$$
\begin{gathered}
\text { FP (it) }=\beta_{0}+\beta_{1} \text { IA (it) }+\beta_{2} \text { LEV (it) }+\beta_{3} \text { Firm-size (it) }+ \\
\beta_{4} \text { ROA (it) }+\varepsilon \text { (it) }
\end{gathered}
$$

FP - Firm performance of firm $i$ at period $t$

IA - Information asymmetry of firm $i$ at period $t$

LEV- Leverage ratio of the firm $i$ at period $t$

ROA- Return on assets ratio of firm $i$ at period $t$

$\varepsilon$ (it) - Error term of firm $i$ at period $t$

Analysis in terms of control variables:

Company size - is very significantly and positively correlated with predictability and presentation of financial statements. This indicates that the larger the company is the better the presentation of financial statements due to availability of information. Joon Chao on "Trading, volume, information asymmetry and timing information [19] suggests that small firms incur high levels of Information Asymmetry. The anticipation is a negative relationship between size and bid-ask spread.

Leverage ratio - a negative correlation of debt ratio and predictability indicates that higher leverage will increase the motives of managers to manipulate the selection of accounting methods in order to enhance earnings which results in reduced shareholder wealth

Return on Assets - Significant and negative correlation between ROA and predictability meaning that the lower the ROA the better the predictability.

\section{Conclusions and Recommendations}

\subsection{Recommendations}

Results show information asymmetry is negatively correlated with firm performance but the relationship is not significant at $5 \%$ level but on a fixed effect inference, information asymmetry is significant at $10 \%$ level.

Using ROA as proxy for firm performance, information asymmetry is negatively correlated to firm performance and the relationship is significant at $1 \%, 5 \%$ and $10 \%$.

This indicates that a $1 \%$ change in information asymmetry will lead to a negative effect on firm performance. Results suggest that performance of the firm to some extend is affected by the level of information asymmetry in the firm.

After controlling return on assets, leverage and capitalization the unobserved motives of the manager while making important decisions for the firm has greater effect on 
firm performance which eventually affects shareholder wealth.

On fixed effect inferences; leverage and Return on Assets are negatively correlated to firm performance while capitalization is positively correlated to firm performance. It's also interesting to note that all the other control variables are insignificant to firm performance with the exception of capitalization that is significant at $1 \%, 5 \%$ and $10 \%$. This means that a percentage increase in capital will lead to an increased level in firm performance.

This is due to the fact that large firms have easier and cheaper access to outside financing per each unit of currency borrowed and this makes it easier to invest in profit making projects. Unlike large firms small firms find it hard to access financing due to risk level involved. Financial institutions do not issue credit to small firms due to perceived inability to repay principal plus interest. Joon Chao on "Trading volume, information asymmetry and timing information [19] suggests that small companies incur high level of information asymmetry anticipating a positive association between firm size and information asymmetry. Larger firms are also thought to be more productive due to better access to technology, available capital for Research and Development, managerial skills to run the business, access to credit from financial institutions and know-how as suggested by Johannes V. Biesebroeck on "Firm size matters" and Laia Castany on "Differences in total factor productivity across firm size" [25 \& 26].

Leverage is negatively correlated to firm performance due to risk. A highly leveraged firm is risky and investors tend to shy away from it because of anticipated inability to repay the loan and fear of bankruptcy risk. However leverage is insignificant on firm performance because a firm could be highly leveraged but operating in a sector that is highly liquid. Such a firm is able to cancel the level of debt with the amount of cash at hand which cancels any negative effect on firm performance.

Return on assets is negatively correlated to firm performance because it is assumed as a firm reaches maturity; returns on assets tend to reduce due to wear and tear of firm assets. Effect is insignificant because larger firms enjoy economies of scale which help reduce any possibility of a greater impact on firm performance.

Information asymmetry has an effect on firm performance because managers are better informed than shareholders; as a result they take advantage of information asymmetry by engaging in unobserved activities that lead to negative effect on firm performance.

\subsection{Conclusions}

Recommendations have been made on ways of mitigating effects of information asymmetry on firm performance. Increased analyst following, auditing of financial statements and listing on capital markets are some of the measures put in place to reduce information asymmetry.

Furthermore, Company board should comprise of external members with an exception of managers whose main objective is to devise new strategies towards achieving shareholders wealth maximization.

An appraisal system should be established as a control unit towards evaluating performance of every employee including managers regarding their output.

Every employee including managers should be rotated from one branch/department to another to avoid misuse of company resources especially cash flows and retained earnings for future investments.

\section{References}

[1] George A. Akerlof, 1970,'the market for lemons: Quality uncertainty and market mechanism'. Quarterly journal of economics, 84(3)488-500.

[2] Michael Spence, 1973. 'Job market signalling'. The quarterly journal of economics, vol.87, no. 3, pp. 355-374.

[3] El Ghoul et al, 2011. 'Does Corporate Social Responsibility Affect the Cost of Capital?' SSRN electronic journal, 35(9) pp2388-2406.

[4] Dan S. Dhaliwal, 2010. 'Voluntary non-financial disclosure and the cost of equity capital: the initiation of corporate social responsibility reporting'. The accounting review 86(1) 2010.

[5] Christian Leuz and Peter Wysocki, 2016. 'The economics of disclosure and financial reporting regulation: evidence

[6] Stewart C Meyers and Nicholas S. Majluf, 1984. 'Corporate financing and investment decisions when firms have information that investors do not have'. Journal of Financial Economics, vol. 13, issue 2, pp. 187-221.

[7] Patricia M. Dichow, 1994. 'Accounting earnings and cash flows as measures of firm performance: The role of accounting accruals'. Journal of accounting and economics, 1994. Vol. 18, issue 1, pp3-42.

[8] Paul M Healy, 1985. 'The effect of bonus schemes of accounting decisions', Massachusetts Institute of Technology, Cambridge, USA 1985. Journal of accounting and economics 1985, pp. 85-107.

[9] B Brian Lee and William Vetter, 2015. 'Critical evaluation of Accrual models in Earnings management studies '. Prairie View A\&M University.

[10] Kenneth Duru and Alexandros Tsitinidis, 2013. 'Managerial incentives and earnings management: An empirical examination of income smoothing in the Nordic Banking'.

[11] Thorsten Broecker, 1990. 'Credit worthiness tests and interbank competition, Econometricia, vol. 58, no.2, pp. 429-452.

[12] Jonathan Berk and Peter Demarzo, 2011. 'Fundamentals of corporate finance'.

[13] Douglas Diamond and Robert E Verrecchia, 1991. 'Disclosure, liquidity and the cost of capital'. Journal of finance, vol. 46, issue 4.

[14] David S Gelb and Paul Zarowin, 2000. 'Corporate disclosure policy and informativeness of stock prices'. Review of accounting studies, 7(1). 
[15] O Kim and Re Verrecchia 1991, 'Trading volume and price reactions to public announcements. Journal of Journal of accounting research, vol. 29, issue 2, pp. 302-321.

[16] Robert E. Verrecchia 2001. 'Information disclosure'. Journal of accounting and economics, vol. 32, issue 1-3, pp. 97-180.

[17] Regina, W. Moerman, 2005. 'Role of information asymmetry and financial reporting quality in debt contracting: evidence from secondary loan market'. The University of Chicago Booth School of Business.

[18] Gary C. Sanger and Geoffrey Booth, 1995. 'Trade size and components of bid-ask spread'. Louisiana State University and Michigan State University.

[19] Joon Chao, 2005. 'Trading volume, information asymmetry and timing information'. The journal of finance, vol. 60, no.1, pp. 413-442.

[20] Shane A. Corwin and Paul Schultz, 'A simple way to estimate bid-ask spreads from daily high and low prices'. Mendoza College of Business at the University Of Notre Dame.

[21] Dou Autore and Tunde Kovacs, 2006. 'The pecking order theory and time -varying adverse selection costs'. University of Massachusetts Lowell.

[22] D. Healey et al, 1992. 'Public Sector Accounting and Financial Control'. Chartered Institute of Public Finance and Accountancy, pp. 309-314.

[23] Arosa et al, 2010, 'The board structure and firm performance in SMEs'.

[24] Gang Wei and Jason Xiao, 'Equity ownership segregation, shareholder preferences and dividend policy in China'. The British Accounting Review, 2009.

[25] Johannes V. Biesebroeck, 2005. 'Firm size matters: growth and productivity growth in African manufacturing'. Economic Development and Cultural Changes, vol. 53, issue 3, pp. 54583.

[26] Laia Castany, 2005. 'Differences in total factor productivity across firm size. Additional analysis'. University of Barcelona.

[27] Albina. Danilova and Christian. Fulliard, 2015. 'Information asymmetry, volatility, liquidity and Tobin tax':

[28] 28. London School of Economics and Political Science, 2014 Social Research Council Discussion paper No.24, 2014.

[29] Wei. Shi and Haifeng. You, 2015. 'Information asymmetry and accounting conservatism: evidence from exogenous shocks to analyst coverage': Hong Kong University of Science and Technology.

[30] 30. 'Empirical investigation of free cash flow hypothesis: Evidence from Jordanian capital market'. Quality of accounting information: Asian Economic and Financial review', 2014.

[31] Mahdi, S. Vahab and Rostam, H. Hesari, 2014. 'Role of information asymmetry in financing methods'. Journal of managing global transition Volume 12 (1) 43-54.

[32] C N. Chiyachantana, N. N and N. Taechapiroontong, 2013. 'The effect of information disclosure on information asymmetry'. Journal of Investment management and Financial Innovations, issue 1, 2013.
[33] 33. Accounting numbers as market valuation substitutes: A study of management buyouts of public stakeholders; the accounting review vol. 6 , no. 3 pp. $400-420$.

[34] Cindy M. Vojtech, 2013. 'Relationship between information asymmetry and dividend policy'. Finance \& Economic Discussion series, Division of research \& Statistics and monetary affairs, Federal Reserve board, Washington DC.

[35] Daniela. Kremslehner and Alexander. Muermann, 2013. 'Asymmetric information in Auto-mobile insurance: Evidence from driving behaviour'. Vienna University of Economics and Business.

[36] Javad. Moradi, Hashem. Valipour and Aida. Dowran, 2013. 'Asymmetric information and the role of accounting in emerging markets: evidence from Tehran Stock Exchange'. Journal of Applied Sciences, Engineering and Technology 5(3)2013.

[37] Patricia. Naranjo., Daniel. Saavedra and Rodrigo, S. Verdi, 2013. 'Financial reporting regulation, information asymmetry and financing decisions around the world'. S loan School of Management, MIT.

[38] Pierre-André and Chiappori B. Salanie, 2013. 'Asymmetric information in insurance markets: Predictions and tests'. Department of Economics, Columbia University.

[39] Robert M. Bushman and Abbie J. Smith, 2013. 'Transparency, financial accounting information and corporate government, FRBNY Economic policy review'

[40] R. Zare. H, Kiafar M. A and Kanani F. Farzantar, 2013. 'Dividend policy from the signalling perspective and its effects on information asymmetry among management and investors'. Research Journal of Applied Sciences, Engineering and Technology, 6(21) 4090-97, 2013.

[41] Thomas D. Fields, Thomas Z. Lys and Linda. Vincent, 2013. 'Empirical research on accounting choice'. Journal of Accounting and Economics 31(2001) 255-302.

[42] Marc S. Rappo, 2010. 'Information asymmetry and the value relevance of cash flow and accounting figures: empirical analysis and implications for managerial accounting'. Problems and Perspectives in Management, Volume 8, Issue 2, 2010.

[43] Paul M. Healy and Krishna G. Palepu, 2009. 'Information asymmetry, corporate disclosure and capital markets'. Journal of Accounting \& Economics 31, nos.1-3(2001):405-440.

[44] The European Journal of Finance, volume 15, issue 4, 2009, pages 385-404. 'Impact of board size on firm performance evidence from the UK'.

[45] Pradeep K. Yadav, Florian. Bardong and Söhnke. M. Bartram, 2009. 'Informed trading, information asymmetry and pricing of information risk: Empirical evidence from NYSE'. Munich Personal RePEC Archive paper No.13586 (2009).

[46] Tony, T. Tang, 2006. 'Information asymmetry and firms credit market access: Evidence from Moody's credit rating format refinement'. University of Chicago, Graduate School of Business.

[47] Robert B. Qichen. Ellen. Engel and Abbie. Smith, 2004. 'Financial accounting information, organizational complexity and corporate governance systems. Journal of accounting and economics, 2004, vol.37 issue 2, 167-201. 
[48] Mark. J. Garmaise and Tobias. J. Moskowitz, 2003. 'Confronting information asymmetry: evidence from real estate markets'. The review of financial studies vol. 17, No.2 pp. 405-437.

[49] James, H. Cardon and Igal. Hendel, 2001. 'Asymmetric information in health insurance: evidence from the medical expenditure survey'. The RAND Journal of Economics, Vol.32, No 3(2001) pp. 408-427.

[50] Christian Leuz and Peter Dwysocki, 2003. 'Earnings management and investor protection: an international comparison'. Journal of financial economics, vol. 69, issue 3.

[51] Robert M. Bushman and Abbie J. Smith, 2001. 'Transparency financial accounting information and corporate governance'. FRBNY Economic Policy Review 2003.

[52] Thomas D. Fields. Thomas Z. Lys and L. Vincent, 2001. 'Empirical research on accounting choice'. Journal of Accounting and Economics 31(2001) 255-307.

[53] Douglas Diamond and Robert E. Verrecchia, 1991. 'Disclosure liquidity and cost of capital'. Journal of finance, vol. 46, issue 4, pp. 1325-59.

[54] Sattar A. Mansi, Darius P. Miller and William F. Maxwell, 2004. 'Does Auditor quality and tenure matter to investors?
Evidence from the bond market'. Journal of Accounting Research, vol 42, pp. 755-793.

[55] Giovanni D. Ariccia, 1998. 'Asymmetric information and the market structure of the banking industry'. International Monetary Fund WP $\backslash 98 \backslash 92$.

[56] 'The role of information asymmetry and financial reporting quality in debt trading: evidence from secondary loan market'. Journal of accounting and economics, 46, 2008.

[57] Paul Healy and James M. Wahlen, 1998. 'Review of earnings management literature and implications for standard setting'. American Accounting Association, Accounting Horizon, Vol. 13, No 4 (1999) pp. 365-383.

[58] Eli. Bartov and Gordon, M. Bodnar, 1995. 'Alternative accounting methods, information asymmetry and liquidity: Theory and evidence'. The Accounting review, Vol. 71, No.3 (1996), pp. 397-418.

[59] Blanca Arosa, 2010. 'Outsiders on the board of directors and firm performance: evidence from Spanish non-listed family firms'. Journal of family business strategy.

[60] Richard A. Heaney, 2007. 'The link between performance and changes in the size and stability of firm's officers and directors'. Journal of multinational financial management. 